\title{
The Essential Oils of Two Achillea L. species from Turkey
}

\author{
Fatma Tosun', Mine Kürkçüoğlu²* \\ ${ }^{1}$ Istanbul Medipol University, School of Pharmacy, Department of Pharmacognosy, 34810 Istanbul, Turkey. \\ ${ }^{2}$ Anadolu University, Faculty of Pharmacy, Department of Pharmacognosy, 26470, Eskişehir, Turkey.
}

\section{ABSTRACT}

Chemical composition of the essential oils obtained by hydrodistillation from the aerial parts of Achillea biebersteinii Afan. and A. wilhelmsii C. Koch were analyzed by GC-FID and GC-MS. The essential oils of $A$. biebersteinii and $A$. wilhelmsii were characterized by the presence of a high percentage of oxygenated monoterpenes $72.9 \%$ and $49 \%$, respectively. Sixty-four compounds were identified in the essential oil of aerial parts of $A$. biebersteinii representing $95.9 \%$ of the essential oil. The main components of $A$. biebersteinii essential oil were 1,8-cineole (34.6\%) and camphor (12.9\%). Fourty-two compounds were identified in the essential oil of aerial parts of A. wilhelmsii representing $88.2 \%$ of the essential oil. Main component of the essential oil of A. wilhelmsii was determined as camphor (32.0\%).

Keywords: Achillea biebersteinii, Achillea wilhelmsii, essential oil, GC-FID and GC-MS.

\section{INTRODUCTION}

Genus Achillea L. (Asteraceae) is represented by more than 140 species in all around the world. The genus is widespread in Europe, Asia, North America and Middle East ${ }^{1}$. There are 59 taxa of Achillea found in Turkey which are divided into 6 sections Ptarmica (DC.) W. Koch, Arthrolepis Boiss., Babounya Boiss., Santalinoidea DC., Millefolium (DC.) W. Koch, and Filipendulinae (DC.) Boiss. Among them, 31 taxa are endemic to Turkey $(\% 53)^{2-4}$. The essential oil composition of several Achillea spp. growing in Turkey have been studied ${ }^{5}$. Antioxidant, insecticidal and herbicidal activities of $A$. biebersteinii oils were reported ${ }^{6-13}$. The antimicrobial activity of $A$. wilhelmsii subsp. wilhelmsii essential oil was tested against several microorganisms and strong inhibitory activity was observed against Enterobacter aerogenes, Proteus vulgaris and Alternaria brassicola ${ }^{14}$ species.

*Corresponding author: Mine Kürkçüoğlu, e-mail: minekurkcuoglu@gmail.com (Received 14 March 2018, accepted 19 March 2018) 
Biological activities of various Achillea species include angiogenic ${ }^{7}$, antifungal ${ }^{8,15}$, antibacterial $^{16}$, antimicrobial ${ }^{14,17}$, hepatoptotective ${ }^{18}$, herbicidal ${ }^{8}$, insecticidal ${ }^{11,19}$, antioxidant ${ }^{16,18}$ antiradical ${ }^{17}$ and protective effects against oxidative stress ${ }^{6,20}$.

In the present work, chemical composition of the Achillea biebersteinii and A. wilhelmsii essential oils were analyzed by gas chromatography (GC) and gas chromatography-mass spectrometry (GC-MS) systems.

\section{MATERIALS AND METHODS}

\section{Plant Materials}

The aerial parts of Achillea biebersteinii Afan. and A. wilhelmsii C. Koch were collected while flowering in the vicinity of Adana and Kayseri, respectively. The plant species were identified by Prof. Mecit Vural and voucher specimens have been deposited at the Herbarium of the Istanbul University, Faculty of Pharmacy, Istanbul, Turkey. (Voucher specimens no: ISTE 115056 and ISTE 115058 resp.)

\section{Isolation of the Essential Oils}

The air-dried plant materials were hydrodistilled for 3 hours using a Clevengertype apparatus. A. biebersteinii and $A$. wilhelmsii oils were dried over anhydrous sodium sulphate and stored at $4{ }^{\circ} \mathrm{C}$ in the dark until analysed. The yield of essential oils were calculated as $0.98 \%$ and $0.18 \%$, v/w on dry weight basis, resp.

\section{GC and GC/MS Conditions:}

The oils were analyzed by capillary GC and GC/MS using an Agilent GC-MSD system.

\section{GC/MS analysis}

The GC/MS analysis was carried out with an Agilent 5975 GC-MSD system. Innowax FSC column (6om x $0.25 \mathrm{~mm}, 0.25 \mu \mathrm{m}$ film thickness) was used with helium as carrier gas (o.8 mL/min.). GC oven temperature was kept at $60^{\circ} \mathrm{C}$ for 10 min and programmed to $220^{\circ} \mathrm{C}$ at a rate of $4^{\circ} \mathrm{C} / \mathrm{min}$, and kept constant at $220^{\circ} \mathrm{C}$ for $10 \mathrm{~min}$ and then programmed to $240^{\circ} \mathrm{C}$ at a rate of $1^{\circ} \mathrm{C} / \mathrm{min}$. Split ratio was adjusted 40:1. The injector temperature was at $250^{\circ} \mathrm{C}$. MS were taken at $70 \mathrm{eV}$. Mass range was from $\mathrm{m} / \mathrm{z} 35$ to 450 .

\section{GC analysis}

The GC analysis was carried out using an Agilent $6890 \mathrm{~N}$ GC system. In order to obtain the same elution order with GC/MS, simultaneous injection was done by using the same column and appropriate operational conditions. FID temperature was $300^{\circ} \mathrm{C}$. 


\section{Identification of Compounds}

Identification of the essential oil components was carried out by comparison of their relative retention times with those of authentic samples or by comparison of their relative retention index (RRI) to series of $n$-alkanes ${ }^{21}$. Computer matching against commercial (Wiley GC/MS Library, MassFinder 3 Library) ${ }^{22,23}$ and in-house "Baser Library of Essential Oil Constituents" built up by genuine compounds and components of known oils, as well as MS literature data ${ }^{24,25}$ was used for the identification. Relative percentage amounts of the separated compounds were calculated from FID chromatograms. The results of analysis are shown in Table 1.

Table 1. Composition of the essential oils of Achillea biebersteinii and A. wilhelmsii

\begin{tabular}{|c|c|c|c|c|}
\hline RRI & Compounds & A \% & B \% & IM \\
\hline 1014 & Tricyclene & $\operatorname{tr}$ & - & MS \\
\hline 1032 & $\alpha$-Pinene & 2.6 & - & $t_{R}, M S$ \\
\hline 1035 & $\alpha$-Thujene & $\operatorname{tr}$ & - & MS \\
\hline 1076 & Camphene & - & 0.4 & $t_{R}, M S$ \\
\hline 1118 & $\beta$-Pinene & 1.1 & - & $t_{R}, M S$ \\
\hline 1132 & Sabinene & 1.1 & 0.4 & $t_{R}, M S$ \\
\hline 1138 & Thuja-2,4 (10)-dien & $\operatorname{tr}$ & - & MS \\
\hline 1188 & $\alpha$-Terpinene & 2.5 & - & $t_{R}, M S$ \\
\hline 1195 & Dehydro-1,8-cineole & $\operatorname{tr}$ & - & $t_{R}, M S$ \\
\hline 1203 & Limonene & 0.2 & 0.2 & $t_{R}, M S$ \\
\hline 1213 & 1,8-Cineole & 34.6 & 3.3 & $t_{R}, M S$ \\
\hline 1255 & $\gamma$-Terpinene & 0.5 & - & $t_{R}, M S$ \\
\hline 1280 & p-Cymene & 3.4 & 0.6 & $t_{R}, M S$ \\
\hline 1290 & Terpinolene & 0.1 & - & $t_{R}, M S$ \\
\hline 1409 & Rosefuran & $\operatorname{tr}$ & - & MS \\
\hline 1437 & $\alpha$-Thujone & 0.2 & - & MS \\
\hline 1445 & Filifolone & 0.3 & - & MS \\
\hline 1451 & $\beta$-Thujone & 0.1 & - & MS \\
\hline 1452 & 1-Octen-3-ol & $\operatorname{tr}$ & - & $t_{R}, M S$ \\
\hline 1474 & trans-Sabinene hydrate & 0.6 & 0.6 & $t_{R}, M S$ \\
\hline 1483 & Isonerol oxide & - & 0.8 & MS \\
\hline 1499 & $\alpha$-Campholene aldehyde & 0.2 & - & MS \\
\hline 1522 & Chrysanthenone & 2.4 & - & MS \\
\hline 1532 & Camphor & 12.9 & 32.0 & $t_{R}, M S$ \\
\hline 1538 & trans-Chrysanthenyl acetate & 2.3 & - & MS \\
\hline 1544 & Dihydroachillene & 0.5 & 0.5 & MS \\
\hline
\end{tabular}




\begin{tabular}{|c|c|c|c|c|}
\hline 1553 & Linalool & 0.2 & 0.7 & $t_{R}, M S$ \\
\hline 1556 & cis-Sabinene hydrate & 0.8 & $\operatorname{tr}$ & $t_{R}, M S$ \\
\hline 1571 & trans-p-Menth-2-en-1-ol & 0.5 & - & MS \\
\hline 1582 & cis-Chrysanthenyl acetate & 0.1 & - & MS \\
\hline 1586 & Pinocarvone & 0.7 & 0.5 & MS \\
\hline 1591 & Bornyl acetate & 0.4 & 0.5 & $t_{R}, M S$ \\
\hline 1600 & Chrysanthenyl propionate & $\operatorname{tr}$ & - & MS \\
\hline 1611 & Terpinen-4-ol & 1.7 & $\operatorname{tr}$ & $t_{R}, M S$ \\
\hline 1612 & $\beta$-Caryophyllene & $\operatorname{tr}$ & 0.8 & $t_{R}, M S$ \\
\hline 1617 & Lavandulyl acetate & - & 2.0 & MS \\
\hline 1638 & cis-p-Menth-2-en-1-ol & 0.4 & - & MS \\
\hline 1648 & Myrtenal & 0.3 & - & MS \\
\hline 1651 & Sabina ketone & 0.2 & - & MS \\
\hline 1670 & trans-Pinocarveol & 0.6 & - & $t_{R}, M S$ \\
\hline 1663 & cis-Verbenol & 0.6 & - & MS \\
\hline 1683 & trans-Verbenol & 4.0 & 0.6 & MS \\
\hline 1687 & Lavandulol & - & 4.1 & $t_{R}, M S$ \\
\hline 1706 & $\alpha$-Terpineol & 3.6 & 1.2 & $t_{R}, M S$ \\
\hline 1719 & Borneol & 2.0 & 2.6 & $t_{R}, M S$ \\
\hline 1725 & Verbenone & 0.1 & - & $t_{R}, M S$ \\
\hline 1726 & Germacrene D & 0.1 & 2.3 & MS \\
\hline 1742 & $\beta$-Selinene & - & 0.4 & MS \\
\hline 1747 & p-Mentha-1,5-dien-8-ol & 0.3 & - & MS \\
\hline 1748 & Piperitone & 0.8 & - & $t_{R}, M S$ \\
\hline 1751 & Bicyclogermacrene & - & 1.5 & MS \\
\hline 1755 & Terpinyl acetate & 6.0 & - & $t_{R}, M S$ \\
\hline 1758 & cis-Piperitol & $\operatorname{tr}$ & - & MS \\
\hline 1764 & cis-Chrysanthenol & 0.7 & - & MS \\
\hline 1776 & $\gamma$-Cadinene & - & 0.6 & MS \\
\hline 1804 & Myrtenol & 0.2 & - & MS \\
\hline 1845 & (E)-Anethole & - & tr & MS \\
\hline 1864 & p-Cymen-8-ol & 0.1 & - & $t_{R}, M S$ \\
\hline 1882 & $\begin{array}{l}\text { 1-Isobutyl 4-isopropyl-2,2-dimethyl } \\
\text { succinate }\end{array}$ & - & $\operatorname{tr}$ & MS \\
\hline 1889 & Ascaridole & 3.1 & - & MS \\
\hline 1900 & Isoshyobunone & - & tr & MS \\
\hline 1916 & Shyobunone & - & 1.5 & MS \\
\hline 1969 & cis-Jasmone & 0.4 & - & MS \\
\hline
\end{tabular}




\begin{tabular}{|c|c|c|c|c|}
\hline 2008 & Caryophyllene oxide & 0.3 & 3.5 & $t_{R}$, MS \\
\hline 2057 & 13-Tetradecanolide & - & 1.9 & MS \\
\hline 2065 & p-Mentha-1,4-dien-7-ol & 0.2 & - & MS \\
\hline 2113 & Cumin alcohol & 0.3 & - & $t_{R}, M S$ \\
\hline 2131 & Hexahydrofarnesyl acetone & - & 0.2 & $t_{R}, M S$ \\
\hline 2144 & Spathulenol & 0.1 & 3.7 & $t_{R}, M S$ \\
\hline 2273 & (2E,6E)-Farnesyl acetate & - & 0.9 & MS \\
\hline 2191 & T-Cadinol & - & 2.2 & MS \\
\hline 2192 & Eugenol & 0.4 & - & $t_{R}, M S$ \\
\hline 2198 & Thymol & 0.1 & 2.6 & $t_{R}, M S$ \\
\hline 2239 & Carvacrol & 0.2 & - & $t_{R}, M S$ \\
\hline 2257 & $\beta$-Eudesmol & 0.1 & 2.6 & MS \\
\hline 2260 & 15-Hexadecanolide & 0.2 & 1.0 & MS \\
\hline 2300 & Tricosane & $\operatorname{tr}$ & - & $t_{R}, M S$ \\
\hline 2316 & Caryophylladienol I & - & 1.2 & MS \\
\hline 2324 & Caryophylladienol II & 0.2 & 4.1 & MS \\
\hline 2353 & Caryophyllenol I & - & 2.2 & MS \\
\hline 2392 & Caryophyllenol II & - & 1.7 & MS \\
\hline 2600 & Hexacosane & 0.1 & - & MS \\
\hline 2607 & Octadecanol & - & 2.3 & MS \\
\hline \multirow[t]{7}{*}{2931} & Hexadecanoic acid & 0.2 & - & MS \\
\hline & Grouped compounds (\%) & & & \\
\hline & Monoterpene hydrocarbones & 12.0 & 2.1 & \\
\hline & Oxygenated monoterpenes & 72.9 & 49.0 & \\
\hline & Sesquiterpenes hydrocarbones & 0.1 & 5.6 & \\
\hline & Oxygenated sesquiterpenes & 0.7 & 22.7 & \\
\hline & Others & 10.2 & 8.8 & \\
\hline
\end{tabular}

RRI: Relative retention indices experimentally calculated against n-alkanes; \%: calculated from FID data; IM: Identification Method: tR, Identification based on comparison with co-injected with standards on a HP Innowax column; MS, identified on the basis of computer matching of the mass spectra with those of the in-house Baser Library of Essential Oil Constituents, Adams, MassFinder and Wiley libraries. A: Achillea biebersteinii Afan., B: A. wilhelmsii C. Koch. 


\section{RESULTS AND DISCUSSION}

A. biebersteinii oils contained camphor and 1,8-cineole as main constituents ${ }^{6}$. In a sample of Ankara origin $\alpha$-terpinyl acetate (7\%) was also encountered in this oil ${ }^{9}$. A sample from Sivas contained 1,8-cineole (31\%), camphor (14\%) $\alpha$-thujone (13\%), p-cymene $(5 \%)$, $\beta$-thujone (3\%), borneol (3\%) as other significant constituents ${ }^{6,10}$.

Camphor (40\%), artemisia alcohol (18\%), yomogi alcohol (16\%), and 1,8-cineole (7\%) were reported as main constituents in A. wilhelmsii oil ${ }^{14}$. Camphor (41\%) was also the main constituent in another study together with caryophylladienol II (6\%), borneol (6\%), camphene (6\%) $)^{6,26}$.

Previously, 1,8-cineole and camphor rich oils were reported by several authors from Achillea species growing outside Turkey ${ }^{6}$.

According to another study which reported the compositions of essential oils of several Achillea species, $A$. biebersteinii has been found to be rich in oxygenated monoterpenes. Piperitone, p-cymene, and camphor were found as main components in the oil of this plant sample, collected from a different locality. ${ }^{1}$

In our present study, we examined chemical composition of essential oils obtained from the aerial parts of $A$. biebersteinii and $A$. wilhelmsii collected in the vicinity of Adana and Kayseri. Yield of essential oils obtained by hydrodistillation for A. biebersteinii and A. wilhelmsii were found to be $0.98 \%$ and $0.18 \%$, respectively. Essential oil components of two Achillea species are seen at Table 1. A bibersteinii and $A$. wilhelmsii oils were characterized by the presence of a high percentage of oxygenated monoterpenes (72.9\% and 49\%). Sixty-four compounds were identified in oil of the aerial parts representing $95.9 \%$ of the A. biebersteinii oil. The main components of the A. biebersteinii oil were 1,8-cineole (34.6\%) and camphor (12.9\%). Fourty-two compounds were identified in oil of the aerial parts representing $88.2 \%$ of the A. wilhelmsii oil. Main component determined for $A$. wilhelmsii is camphor (32.0\%). These compounds have also been previously reported in Achillea essential oils ${ }^{6}$.

\section{ACKNOWLEDGMENT}

We thank Prof. Mecit Vural for identification of the plant materials.

\section{REFERENCES}

1. Kose, Y. B.; B. Demirci and G. İscan. Volatile Oil Composition and Biological Activity of Achillea biebersteinii Afan. and Achillea teretifolia Willd., Fresenius Enviromental Bulletin, 2017, $26(8), 5213-5218$.

2. Arabacı T. Achillea L. In A Checklist of the Flora of Turkey (Vascular Plants), Güner, A.; Aslan, S.; Ekim, T.; Vural, M. and Babaç M.T., Eds.; Nezahat Gokyigit Botanik Bahcesi ve Flora Araştırmaları Dernegi Yayını, Istanbul, 2012; 108-112. 
3. Huber-Morath A. Achillea L. In Flora of Turkey and the East Aegean Islands, vol. 5. Davis P.H., Ed.; Edinburgh University Press, Edinburgh, 1975; pp 224-252.

4. Tabanca, N.; Demirci, B.; Aytac, Z. and Baser K.H.C. Chemical composition of Achillea schischkinii Sosn., an endemic species from Turkey, Nat. Volatiles \& Essent. Oils, 2016, 3(4): 24-28.

5. Kürkçüoğlu, M.; Demirci, B.; Tabanca, N.; Özek, T. and Başer K.H.C. The Essential Oil of Achillea falcata, Flavour Fragr. J. 2003, 18, 192-194.

6. Baser, K.H.C. Essential Oils of Achillea Species of Turkey, Nat. Volatiles \& Essent. Oils, 2016, 3(1), 1-14.

7. Demirci, F.; Kiyan, H. T.; Demirci, B. \& Baser, K. H. C. The in vivo angiogenic evaluation of Achillea biebersteinii Afan. and Achillea teretifolia Willd. essential oils. Planta Medica, 2011, 77(12), 1391-1391.

8. Kordali, S.; Cakir, A.; Akcin, T.A.; Mete, E.; Akcin, A.; Aydin, \& T., Kilic. Antifungal and herbicidal properties of essential oils and n-hexane extracts of Achillea gypsicola Hub.-Mor. and Achillea biebersteinii Afan. (Asteraceae). Ind. Crop. Prod. 2009, 29, 562-570.

9. Kusmenoglu, S.; Baser, K. H. C.; Ozek, T.; Harmandar, M. \& Gokalp, Z. Constituents of the Essential Oil of Achillea biebersteinii Afan. J. Essent. Oil Res. 1995, 7(5), 527-528.

10. Polatoglu, K.; Karakoc, O. C. \& Goren, N. Phytotoxic, DPPH scavenging, insecticidal activities and essential oil composition of Achillea vermicularis, A. teretifolia and proposed chemotypes of A. biebersteinii (Asteraceae). Industrial Crops and Products, 2013, 51, 35-45.

11. Tabanca, N.; Demirci, B.; Gurbuz, I., Demirci, F.; Becnel, J. J.; Wedge, D. E. \& Baser, K. H.

C. Essential Oil Composition of Five Collections of Achillea biebersteinii from Central Turkey and their Antifungal and Insecticidal Activity. Natural Product Communications, 2011, 6(5), 701-706.

12. Techen, N.; Tabanca, N.; Demirci, B.; Gurbuz, I.; Pan, Z.; Khan, I. A.; Wedge, D.E. \& Baser, K. H. C. Chemical Characterization and Genomic Profiling of Achillea biebersteinii from Various Localities in Central Turkey. Planta Medica, 2oo9, 75(4), 416-416.

13. Toncer, O.; Basbag, S.; Karaman, S.; Diraz, E. \& Basbag, M. Chemical Composition of the Essential Oils of some Achillea Species Growing Wild in Turkey. International Journal of Agriculture and Biology, 2010, 12(4), 527-530.

14. Azaz, A. D.; Arabaci, T.; Sangun, M. K. \& Yildiz, B. Composition and the in vitro antimicrobial activities of the essential oils of Achillea wilhelmsii C. Koch. and Achillea lycaonica Boiss \& Heldr. Asian Journal of Chemistry, 2oo8, 20(2), 1238-1244.

15. Amjad, L.; Mousavidehmourdi, K.; Rezvani, Z. In vitro Study on Antifungal Activity of Achillea wilhelmsii Flower Essential Oil Against Twenty Strains of Candida albicans, Chiang Mai Journal of Science, 2014, 14, 1058-1064.

16. Alfatemi, S.M.H.; Rad, J.S.; Rad, M.S.; Mohsenzadeh, S.; Teixeira da Silva, J.A. Chemical composition, antioxidant activity and in vitro antibacterial activity of Achillea wilhelmsii $\mathrm{C}$. Koch essential oil on methicillin-susceptible and methicillin-resistant Staphylococcus aureus spp., 3 Biotech 2015, 5(1) 39-44.

17. Sokmen, A.; Sokmen, M.; Daferera, D.; Polissiou, M.; Candan, F.; Unlu, M. \& Akpulat, H.A. The in vitro antioxidant and antimicrobial activities of the essential oil and methanol extracts of Achillea biebersteinii Afan. (Asteraceae). Phytother. Res. 2004, 18, 451-456. 
18. Al-Said, M.S.; Mothana, R.A.; Al-Yahya, M.M.; Rafatullah, S.; Al-Sohaibani, M.O.; Khaled, J.M.; Alatar, A.; Alharbi, N.S.; Kurkcuoglu, M. and Baser, K.H.C. GC-MS Analysis: In Vivo Hepatoprotective and antioxidant Activities of the Essential Oil of Achillea biebersteinii Afan. growing in Saudi Arabia, Evidence-Based Comp and Alt Med, 2016, Article ID 1867048.

19. Khani, A.; Asghari, J. Insecticide activity of essential oils of Mentha longifolia, Pulicaria gnaphalodes and Achillea wilhelmsii against two stored product pests, the flour beetle, Tribolium castaneum, and the cowpea weevil, Callosobruchus maculates. J. Insect Sci. 2012, 12, 73. 20. Dadkhah, A.; Fatemi, F.; Alipour, M.; Ghaderi, Z.; Zolfaghari, F. \& Razdan, F. Protective effects of Iranian Achillea wilhelmsii essential oil on acetaminophen-induced oxidative stress in rat liver, Pharm. Biol. 2015, 53(2) 220-227.

21. Curvers, J.; Rijks, J.; Cramers, C. A. M. G.; Knauss, K. \& Larson, P. Temperature programmed retention indices: Calculation from isothermal data. Part 1: Theory. Journal of Separation Science, 1985, 8(9), 607-610.

22. McLafferty, F. W.; Stauffer, D. B. The Wiley/NBS Registry of Mass Spectral Data; J. Wiley and Sons: New York, 1989.

23. Koenig, W. A.; Joulain, D.; Hochmuth, D. H. Terpenoids and related constituents of essential oils. MassFinder 3. Hamburg, Germany: Hochmuth Scientific Consulting, 2004

24. Joulain, D.; Koenig, W. A. The Atlas of Spectra Data of Sesquiterpene Hydrocarbons. E.B.Verlag Hamburg, 1998.

25. ESO 2000. The Complete Database of Essential Oils. Boelens Aroma Chemical Information Service: The Netherlands, 1999.

26. Turkmenoglu, F.P.; Agar, O.T.; Akaydin, G.; Hayran, M.; Demirci, B. Characterization of volatile compounds of eleven Achillea species from Turkey and biological activities of essential oil and methanol extract of A. hamzaoglui Arabaci et Budak, Molecules. 2015, 20, 11432-11458. 